\title{
Could the Ease of Doing Business be considered a predictor of countries' Socio-Economic Wealth? An empirical analysis using PLS-SEM
}

\author{
Antonio L. Leal-Rodríguez \\ Faculty of Economics and Business Science, Universidad de Sevilla, \\ Sevilla, Spain \\ aleal6@us.es \\ Carlos Sanchís-Pedregosa \\ Faculty of Business Science, Universidad del Pacifico, \\ Lima, Peru \\ c.sanchisp@up.edu.pe \\ Faculty of Economics and Business Science, Universidad de Sevilla, \\ Sevilla, Spain \\ csanchis@us.es
}

Abstract. The wealth of nations differs significantly due to different factors. One of the reasons identified by previous studies is the level of entrepreneurship promotion by governments. This aspect has scarcely been studied empirically to date. Therefore, this paper sheds some light on this regard through building a construct out of ten Ease of Doing Business Index (EDBI) measures developed by the World Bank and relating it with a construct shaped by two measures of socio-economic wealth (SEW), namely gross domestic product and the Human Development Index. To this end, we conduct a structural equation model analysis using partial least squares (PLS-SEM) method with a 2018 database comprising secondary data from 190 countries. As the main contribution of this study, the results show that good performance in the EDBI ranking predicts good performance in the SEW ranking. Additionally, this study is pioneer in the use of these rankings to build composite constructs (latent variables) and relate them. For these reasons, our findings are useful for both academia and governments responsible for promoting entrepreneurship, as this latter is identified as the key enabler of economic development.

Keywords: ease of doing business, socio-economic wealth, gross domestic product, Human Development Index, PLS-SEM.

JEL Classification: L26, O11. 


\section{INTRODUCTION}

Factors involved in determining the socioeconomic level development of nations are common subjects in a large number of research studies to date. However, this area still requires further analysis (Mongay, 2018). Specifically, a government role as facilitator of enterprises' creation is identified as the key issue for economic growth of regions (Ruiz, Cabello and Pérez-Gladish, 2018). For this reason, entrepreneur abilities to modify their environment through leveraging opportunities resulted from wealth creation, as Wang (2017) pointed out, need to be strengthened, or at least not hindered, by governments serving to develop their potential (Szirmai, Naudé and Goedhuys, 2011). Therefore, entrepreneurship is considered a driver of economic change and for some authors such as Greenspan and Wooldridge (2018, as cited in Book, 2019) both are interchangeable terms in countries like America.

Since 2002, the World Bank Group has been developing its Doing Business project, aimed at providing impartial and objective measures of national business regulations (Doing Business, 2018). According to their ease of doing business, these reports rank countries from 1st to 190th place. The higher an economy appears in this ranking, the more favorable its business regulatory environment is in relation to launching and development of enterprises. The Ease of Doing Business Index (EDBI) is made up by the aggregation of the scores on the ten following topics:

1. Starting a Business.

2. Dealing with Construction Permits.

3. Getting Electricity.

4. Registering Property.

5. Getting Credit.

6. Protecting Minority Investors.

7. Paying Taxes.

8. Trading across Borders.

9. Enforcing Contracts.

10. Resolving Insolvency.

Linkages between the fostering of entrepreneurship and socioeconomic wealth of nations have been reasoned from a theoretical approach. Nevertheless, an empirical approach, involving data collection and analysis, might be needed to explore the existence of a relationship between the ease of doing business and socioeconomic wealth. Regarding this, we try to relate the EDBI with Socio-Economic Wealth (SEW) measures in order to assess a potential predictive relationship between them. Specifically, this paper carries out a structural equation model analysis through the use of partial least squares (PLS-SEM) with a 2018 database comprising secondary data from 190 countries (see Appendix section). This study is pioneer in the use of these rankings to build composite constructs and relate them. The following sections will present the conceptual model, methods used to reach our objectives, ending with the results and conclusions sections.

\section{LITERATURE REVIEW}

As pointed by Ruiz, Cabello and Pérez-Gladish (2018), investment location decisions may entail the entrepreneur to focus on those countries where such investments seem more accurate, wiser and secure. In this vein, effective and transparent business regulatory systems developed by governments that enable entrepreneurship is a research subject requiring a deeper analysis. However, this is a rather complex topic, taking into account the diverse array of factors that might influence an entrepreneur choice (i.e., business atmosphere, the human development level, political and macroeconomic stability). 
This topic has been deeply addressed from a theoretical point of view framed within the Austrian School of Economics. Recently, based on the ideas of entrepreneurial spirit and spontaneous order (von Mises, 2004; Hayek, 1960), Huerta-De Soto (2010) defines entrepreneurship as a dynamic process of discovering, recognizing and seizing opportunities to achieve an end or obtain profits, and act accordingly to take advantage of these opportunities that arise in the environment. For instance, as stated by Szirmai, Naudé and Goedhuys (2011), socio-economic development needs continued and shared escalations in GDP per capita jointly with progressive fundamental changes in the settings and productive structure of economy towards goods manufacture. Consequently this leads to higher value-added and the introduction of more efficient production techniques. In this vein, entrepreneurs might foster a country's economic growth by enabling the rearrangement of resources to more productive applications (Acs and Storey 2004), carrying out essential economic functions (e.g. reducing costs, filling market gaps, completing inputs) (Szirmai et al., 2011) and upholding structural adjustment (Gries and Naudé 2009).

Several studies are based on the World Bank Group's Doing Business database (i.e. Schueth, 2010, 2015; Cooley, 2015) and pointed out the existence of certain significant methodological flaws. Furthermore, an independent evaluation study suggested the need for developing more informative rankings (World Bank, 2008; Ruiz et al., 2018). Thus, the relationship between the ease of doing business and socio-economic remains unclear as prior research has conducted to inconclusive results. As suggested by Szirmai et al. (2011, p. 28) "At the top of the agenda, remains the question why in some cases the institutional environment effectively stifles innovative behaviour, while other times entrepreneurs can find a way around the obstacles". Hence, scholars ought to address efforts to analyze and understand the interplay between the fields of entrepreneurship and development economics.

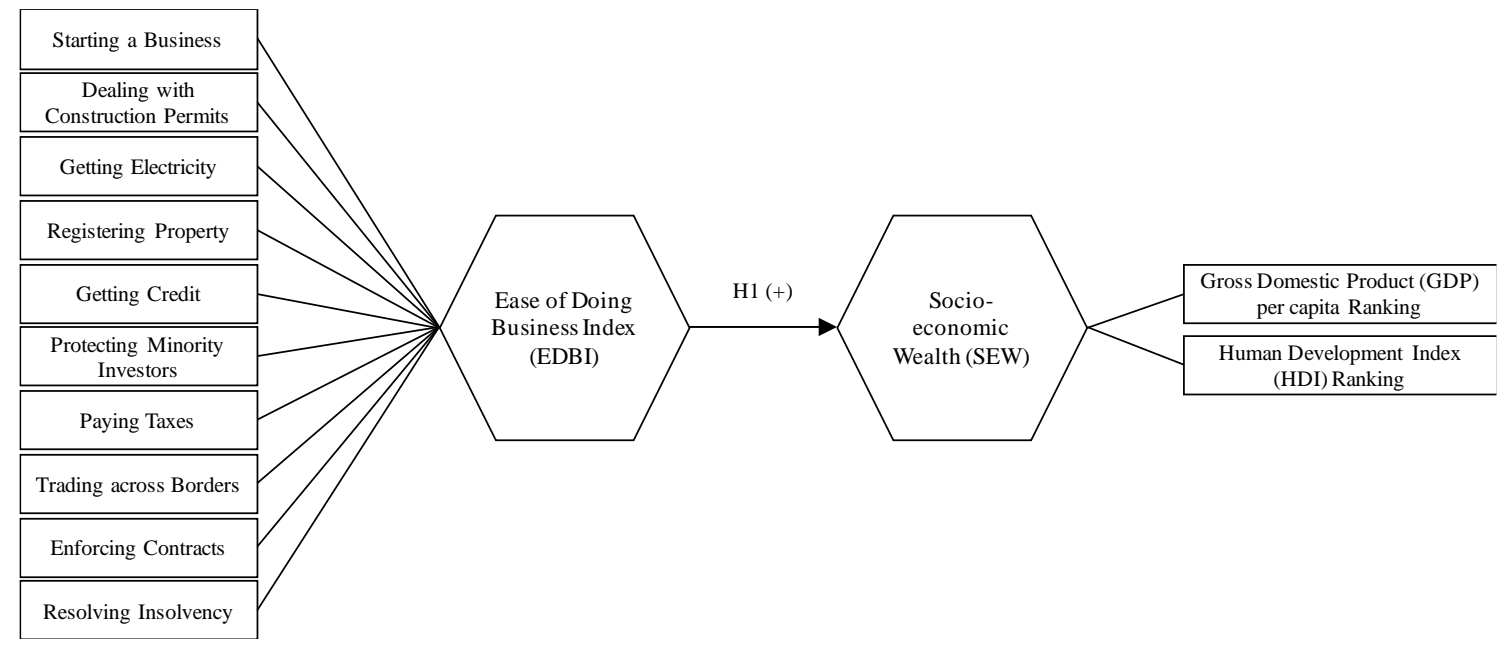

Figure 1. Conceptual model

In light of the above, this paper attempts to narrow this gap by analyzing the extent to which EDBI empirically predicts socio-economic wealth. For this purpose, this paper empirically assesses the causal relationships between the exogenous variable, EDBI, and the endogenous variable, SEW. Both composite variables shaped by ten and two dimensions, respectively. We empirically test our research hypothesis assess in a sample comprising 190 countries by the use of Partial Least Squares - Structural Equations Modeling (PLS-SEM) technique. 


\section{METHODOLOGY}

\subsection{Data collection}

This study is based on secondary data belonging to diverse data repositories. Precisely, the data corresponding to the EDBI indicators was obtained from the World Bank 'Doing Business Ranking' (2018). Regarding the data indicators shaping the socio-economic wealth, GDP per capita ranking indicators were taken from the International Monetary Fund (2017), and HDI ranking indicators came from the United Nations Development Programme's Human Development Report (2018).

Assessing the Ease of Doing Business essentially bears on the enterprise day-to-day activities jointly with the facilities or obstacles they have to face while observing national, regional or local business regulation. GDP per capita comprises the total aggregate value of the goods and services produced within a nation in a year, divided by its number of inhabitants. Instead, the HDI is a composite statistic shaped by life expectancy, education, and income per capita indicators. A country scores higher HDI when the life expectancy at birth is longer, the education period is longer, and the income per capita is higher. Likewise, it is used to distinguish amongst developed, a developing or underdeveloped countries.

\subsection{Data analysis}

\subsubsection{Descriptive statistics}

We carefully checked the data in terms of its descriptive statistics, correlations and normality. This way, Table 1 comprises information regarding the missing, mean, median, minimum, maximum, standard deviation, kurtosis and skewness values. The hypothesis test regarding normally distribution of the dependent variable was performed by Shapiro-Wilk test of normality through JASP package (2019). As it is shown in Table 2, The p-values are significant, meaning there is statistical reason for endorsing the deviation from normality of the dependent variables. Finally, Tables 6 and 7 (Appendix section) comprise the raw data and indicators correlations, respectively.

Table 1

Summary of descriptive statistics

\begin{tabular}{|l|c|c|c|c|c|c|c|c|}
\hline & Missing & Mean & Median & Min & Max & $\begin{array}{c}\text { Standard } \\
\text { Deviation }\end{array}$ & $\begin{array}{c}\text { Excess } \\
\text { Kurtosis }\end{array}$ & Skewness \\
\hline GDP pc & 2 & $20,277.798$ & $13,000.000$ & 600 & 128,378 & $21,366.694$ & 4.432 & 1.853 \\
\hline Ranking GDP pc & 0 & 95.500 & 96 & 1 & 190 & 54.848 & -1.200 & 0.000 \\
\hline HDI & 10 & 634.839 & 713 & 7 & 953 & 255.442 & 0.415 & -1.107 \\
\hline Ranking HDI & 10 & 94.467 & 94 & 1 & 190 & 54.890 & -1.200 & 0.030 \\
\hline Global Rank & 0 & 95.495 & 96 & 1 & 190 & 54.840 & -1.200 & -0.000 \\
\hline Business Opening & 0 & 95.468 & 96 & 1 & 190 & 54.855 & -1.199 & -0.000 \\
\hline Building Permits & 0 & 95.447 & 96 & 1 & 186 & 54.759 & -1.207 & -0.005 \\
\hline Electricity Obtaining & 0 & 95.458 & 96 & 1 & 187 & 54.807 & -1.204 & -0.004 \\
\hline Property Registration & 0 & 95.453 & 96 & 1 & 187 & 54.786 & -1.204 & -0.003 \\
\hline Credit Obtaining & 0 & 90.316 & 85 & 1 & 186 & 54.880 & -1.199 & 0.065 \\
\hline Protection Minority Investors & 0 & 92.468 & 95 & 1 & 190 & 54.737 & -1.179 & 0.045 \\
\hline Taxes Payment & 0 & 95.474 & 96 & 1 & 190 & 54.860 & -1.200 & -0.001 \\
\hline Cross-border Trade & 0 & 94.858 & 96 & 1 & 189 & 55.853 & -1.144 & -0.054 \\
\hline Contracts Fulfillment & 0 & 95.474 & 96 & 1 & 190 & 54.850 & -1.200 & 0.001 \\
\hline Insolvency Resolution & 0 & 94.147 & 96 & 1 & 168 & 52.850 & -1.283 & -0.099 \\
\hline
\end{tabular}


Test of Normality (Shapiro-Wilk)

\begin{tabular}{|c|c|c|}
\hline Dependent variable & W & $\mathrm{p}$ \\
\hline Ranking GDP pc & 0.955 & $<.001$ \\
\hline Ranking HDI & 0.427 & $<.001$ \\
\hline
\end{tabular}

Note. Significant results suggest a deviation from normality.

\subsubsection{PLS analysis}

To empirically test the hypothesis posited within this study, this paper relies on the use of Partial Least Squares (PLS) path-modeling, a variance-based structural equation modeling (VBSEM) technique (Roldán and Sánchez-Franco, 2012). The main reason underlying this decision refers to the composite nature of the two constructs under assessment in our research model. Although Granger causality statistical hypothesis test would have been equally useful according to our research purpose of predicting causality, this study works with composite constructs that consequently requires a different approach. Prior studies endorse the use of PLS when a composite measurement model is supported (Felipe et al., 2017). Both theoretical studies (Rigdon, 2012; Rigdon, Sarstedt, \& Ringle, 2017) and empirical simulation works (Becker, Rai, \& Rigdon, 2013; Sarstedt, Hair, Ringle, Thiele, \& Gudergan, 2016) endorse and advice the use of PLS-SEM for models comprising composite constructs. In addition, this study is primarily focused on the prediction of the dependent construct -SEW- (Hair, Ringle and Sarstedt, 2011). The exogenous construct -EDBI- was modeled as a composite and was estimated in Mode B (regression weights), while Mode A (correlation weights) was chosen for measuring the endogenous construct -SEW-. Furthermore, SmartPLS 3.2.7 software was used (Ringle, Wende and Becker, 2015).

\section{EMPIRICAL RESULTS}

\subsection{Evaluation of the measurement model}

The assessment of the PLS measurement model displays satisfactory results. Firstly, regarding the Socio-Economic Wealth construct, it has been modeled as a composite construct in Mode A. This requires that the evaluation of the measurement model may comprise the following assessments: (i) individual item reliability, (ii) construct reliability, (iii) convergent validity and (iv) discriminant validity. The indicators meet the requirement of individual item reliability, since the outer loadings are both over the 0.707 threshold (Table 3). Besides, this construct satisfies the requirements of construct reliability, as its Cronbach's Alpha and Composite Reliability are greater than 0.7 (Table 3), and convergent validity, as its average variance extracted (AVE) is over the 0.5 critical level (Table 3). Finally, Table 3 discloses that discriminant validity is attained, according to the heterotrait-monotrait ratio (HTMT) criterion (Henseler et al., 2015), which indicates that values ought to be under the threshold of 0.85 (Kline, 2015).

Secondly, the ease of doing business construct has been modeled as composite construct in Mode B. Therefore, it must be assessed in terms of (i) potential multicollinearity between items and (ii) weight assessment (Roldán and Sánchez-Franco, 2012). Following Petter, Straub and Rai (2007) variance inflation factor (VIF) values that surpass the threshold of 3.3 denotes the existence of high multicollinearity between items. Nevertheless, Ringle, Wende and Becker (2015) suggest that multicollinearity should be a serious concern when VIF values are over the critical level of 5. In our case (Table 3), the maximum VIF value for indicators ascends to 2.537, standing below the thresholds proposed by Ringle et al. (2015) and Petter et al. 
(2007). Thus, multicollinearity is not a concern in our study. Subsequently, it is necessary to examine the magnitude and significance of the weights (Table 3). Weights provide information concerning how each item contributes to the respective composite (Chin, 1998), enabling to rank the indicators on the basis of their contribution.

Table 3

Measurement model assessment

\begin{tabular}{|c|c|c|c|c|c|c|}
\hline Construct/Indicators & $\begin{array}{c}\text { Outer } \\
\text { loadings }\end{array}$ & $\begin{array}{c}\text { Outer } \\
\text { weights }\end{array}$ & VIF & $\begin{array}{c}\text { Cronbach's } \\
\text { Alpha }\end{array}$ & $\begin{array}{l}\text { Composite } \\
\text { Reliability }\end{array}$ & AVE \\
\hline Ease of Doing Business & & & & 0.914 & 0.909 & 0.507 \\
\hline Dealing with construction permits & 0.736 & 0.214 & 1.893 & & & \\
\hline Starting a Business & 0.552 & -0.087 & 1.823 & & & \\
\hline Enforcing contracts & 0.764 & 0.184 & 2.128 & & & \\
\hline Getting Credit & 0.424 & -0.108 & 1.613 & & & \\
\hline Trading across Borders & 0.785 & 0.174 & 2.236 & & & \\
\hline Getting Electricity & 0.866 & 0.323 & 2.299 & & & \\
\hline Resolving Insolvency & 0.782 & 0.295 & 2.537 & & & \\
\hline Registering Property & 0.707 & 0.012 & 2.379 & & & \\
\hline Protecting Minority Investors & 0.633 & 0.023 & 2.274 & & & \\
\hline Paying Taxes & 0.765 & 0.164 & 2.141 & & & \\
\hline Socio-Economic Wealth & & & & 0.933 & 0.968 & 0.937 \\
\hline Ranking GDPpc & 0.966 & 0.496 & 4.272 & & & \\
\hline Ranking HDI & 0.971 & 0.537 & 4.272 & & & \\
\hline \multicolumn{7}{|c|}{ Heterotrait-Monotrait Ratio (HTMT) } \\
\hline & \multicolumn{3}{|c|}{ Ease of Doing Business } & \multicolumn{2}{|c|}{ Socio-Economic Wealth } & \\
\hline \multicolumn{7}{|l|}{ Ease of Doing Business } \\
\hline Socio-Economic Wealth & \multicolumn{3}{|c|}{0.806} & & & \\
\hline
\end{tabular}

Note: VIF: Variance Inflation Factor; AVE: Average Variance Extracted; N.A.: Non Applicable.

\subsection{Evaluation of the structural model}

As suggested by Hair et al. (2014), this study applies a bootstrapping (5,000 resamples) technique to generate the standard errors, t-statistics, p-values and $95 \%$ bias corrected confidence intervals (BCCI) that permit the evaluation of the statistical significance for the relationships hypothesized in the conceptual model. Table 4 presents the main parameters that are obtained for the structural model under assessment in this paper. The coefficient of determination $\left(\mathrm{R}^{2}\right)$ is employed as the main criterion for measuring explained variance -the extent to which exogenous constructs explain endogenous constructs-. The outcomes contained in Table 4 show that the structural model attains acceptable predictive relevance for the endogenous construct, given that the $\mathrm{R}^{2}$ coefficient is equal to 0.638 (Table 4). Moreover, the direct relationship hypothesized between EDBI and SEW is shown to be positive and significant. 
Structural model results

\begin{tabular}{|c|c|c|c|c|c|c|c|}
\hline \multirow{2}{*}{ Relationship } & \multirow{2}{*}{$\begin{array}{l}\text { Coefficient of } \\
\text { Determination }\end{array}$} & \multirow{2}{*}{$\begin{array}{c}\text { Path } \\
\text { coefficient }\end{array}$} & \multirow{2}{*}{ T Statistics } & \multirow{2}{*}{ P-value } & \multicolumn{2}{|c|}{$95 \%$ BCCI } & \multirow{2}{*}{ Support } \\
\hline & & & & & $2.5 \%$ & $97.5 \%$ & \\
\hline $\begin{array}{c}\text { Ease of Doing business } \rightarrow \\
\text { Socio-Economic Wealth }\end{array}$ & $\mathrm{R}^{2}=0.638$ & $0.799 * * *$ & 32.045 & 0.000 & 0.728 & 0.834 & Yes \\
\hline
\end{tabular}

Note: Bootstrapping 95\% bias corrected confidence intervals (based on $\mathrm{n}=5000$ subsamples). ***p b .001; ** p b .01; *p b .05

\subsection{Evaluation of the predictive ability model}

This study also assesses whether this model entails predictive ability. In this line, Shmueli and Koppius (2011) label a model's predictive performance as its ability to generate precise predictions of new observations, whether they are temporal or cross-sectional. Furthermore, Shmueli (2010) posits that explanation and prediction involve two distinctive purposes that could be combined in a research study. Such view is also shared by Dolce, Vinzi and Lauro (2017, p. 169), who argue that "The predictions of path models should be sensitive to the theory. In particular, the theoretical model represented by the structural equations and prediction should not be separated".

Hence, this study assesses the predictive ability (out-of-sample prediction) of the proposed conceptual model by using cross-validation with holdout samples (Evermann and Tate, 2016) focusing on the key endogenous construct (SEW). Concretely, this paper makes use of the PLS predict algorithm (Shmueli et al, 2016) available in the SmartPLS software version 3.2.7. (Ringle et al, 2015).

To evaluate if the model entails predictive ability it is required to check the $\mathrm{Q}^{2}$ value. $\mathrm{Q}^{2}$ values greater than 0 imply that the prediction error of PLS results are smaller than the prediction error of merely using the mean values. Therefore, reaching positive $\mathrm{Q}^{2}$ values implies that the proposed conceptual model attains appropriate predictive ability. The conceptual model proposed within this paper fulfills this criterion both at the construct (i.e., SEW), and at the dimension (Ranking GDP pc and Ranking HDI) levels (Table 5).

Table 5

Predictive performance summary

\begin{tabular}{|c|c|c|c|}
\hline \multicolumn{4}{|c|}{ LV Prediction Summary } \\
\hline & RMSE & MAE & $\mathrm{Q}^{2}$ \\
\hline Socio-Economic Wealth & 0.546 & 0.430 & 0.584 \\
\hline \multicolumn{1}{|c|}{ PLS } & MAE & $\mathrm{Q}^{2}$ \\
\hline Ranking GDP pc & RMSE & 29.841 & 0.504 \\
\hline Ranking HDI & 38.818 & 27.375 & 0.604 \\
\hline
\end{tabular}

\section{DISCUSSION AND CONCLUSIONS}

As it was pointed out before, not many studies have empirically attempted to test whether there is a positive relationship between the ease of doing business and socio-economic wealth. This paper sheds some light upon this research gap and empirically analyzes the extent to which EDBI predicts socio-economic wealth. Results derived from the use of Partial Least Squares - Structural Equations Modeling (PLS-SEM) technique reveal that there is a positive and significant link between the EDBI and the socio-economic 
wealth of nations. This could be considered an important contribution, bearing in mind that previous studies were unable to set that relation. However, not only the positive relation could be demonstrated but a predictive ability of the model. Therefore, it is possible to establish that the EDBI is a predictor of SEW. Consequently, it seems likely that the more obstacles to free trade a government introduces, the lower its socio-economic wealth level will be.

In this line, the Austrian school of economics, firmer than any other school of economic thought, has disapproved almost all forms of governmental interference in the market -particularly inflation, price controls, barriers to free market and schemes for redistribution of wealth or income-, arguing that such interventions typically contribute to erode the incentives, to generate distortions in production, as well as shortages, demoralization, and other undesirable effects. Moreover, Friedrick A. Hayek remarkably argued that those grand and ambitious governmental plans frequently lead to unintended consequences. In fact, such view became the intellectual rationale behind Ronald Reagan's and Margaret Thatcher's economic agendas of the 1980s and 1990s (Fukuyama, 2011). In his work "The Constitution of Liberty", Hayek (1960) develops further this view of the limits of human cognition and claims that governments are not able to discern sufficiently about a society to be able to plan accurately.

Among the main practical implications of these results, it is important to note that a government's more suitable role should be somehow more modest, limited to the creation of laws that generally and equally applied may represent the ground upon which spontaneous interactions among individuals might happen (Fukuyama, 2011). It is only within this social order that Hayek delimits the role governments should adopt in society. Thus, governments must merely exist to deliver a ground or structure within which human collaboration is maximized (Andrieu, 2010). Finally, it would be useful to perform confirmatory tests of these results through a longitudinal study or other methodological approaches.

\section{REFERENCES}

Acs, Z. J., \& Storey, D. J. (2004). Introduction: Entrepreneurship and economic development. Regional Studies. https://doi.org/10.1080/0034340042000280901

Andrieu, E. C. (2010, April). The entrepreneur according to the Austrian school. In Businesses Report OPENS Forum (2014): Study Reports On Growth of Women-Owned Businesses. Retrieved from http://hdl.handle.net/10500/3779\%3E

Becker, J.-M., Rai, A., \& Rigdon, E. (2013). Predictive validity and formative measurement in structural equation modeling: Embracing practical relevance. Proceedings of 34th International Conference on Information Systems, Milan, 119.

Book, J. (2019). [Review of the book Capitalism in America: A History by A. Greenspan \& A. Wooldridge]. The QuarTerly Journalof AusTrian Economics, 22(1), 82-90. Retrieved from https:/ / qjae.scholasticahq.com/article/9142

Chin, W. W. (1998). The partial least squares approach for structural equation modeling. In G. A. Marcoulides (Ed.), Methodology for business and management. Modern methods for business research (pp. 295-336). Mahwah, NJ, US: Lawrence Erlbaum Associates Publishers.

Cooley, A. (2015). The emerging politics of international rankings and ratings. In A. Cooley \& J. Snyder (Eds.), Ranking the World: Grading States as a Tool of Global Governance (pp. 1-38). Cambridge: Cambridge University Press. doi:10.1017/CBO9781316161555.002

Dolce, P., Vinzi, V. E., \& Lauro, C. (2017). Predictive path modeling through PLS and other component-based approaches: Methodological issues and performance evaluation. In Partial Least Squares Path Modeling (pp. 153172). Springer, Cham. https://doi.org/10.1007/978-3-319-64069-3_7

Evermann, J., \& Tate, M. (2016). Assessing the predictive performance of structural equation model estimators. Journal of Business Research, 69(10), 4565-4582. https://doi.org/10.1016/j.jbusres.2016.03.050

Felipe, C., Roldán, J., \& Leal-Rodríguez, A. (2017). Impact of organizational culture values on organizational agility. Sustainability, 9(12), 2354. https://doi.org/10.3390/su9122354 
Fukuyama, F. (2011). Friedrich A. Hayek, Big-Government Skeptic. The New York Times, p. BR12. Retrieved from https://www.nytimes.com/2011/05/08/books/review/f-a-hayek-big-government-skeptic.html

Gries, T., \& Naudé, W. (2010). Entrepreneurship and structural economic transformation. Small Business Economics, 34(1), 13-29. https://doi.org/10.1007/s11187-009-9192-8

Hair, J.F., Ringle, C.M. and Sarstedt, M. (2011). PLS-SEM: Indeed, a Silver Bullet. Journal of Marketing Theory and Practice, 19, 139-151. https://doi.org/10.2753/MTP1069-6679190202

Hayek, F. A. (1960). The Constitution or Liberty. Chicago: University of Chicago Press.

Huerta-De Soto, J. H. (2010). Socialism, economic calculation and entrepreneurship. Edward Elgar.

JASP Team (2019). JASP (Version 0.11.1) [Computer software].

Kline, R. B. (2015). Principles and practice of structural equation modeling. Guilford publications.

von Mises, L. (2004). Abstract of Human Action, treatise of economy. Paris, Les belles lettres.

Mongay, J. (2018). Ease of Doing Business and Wealth Creation. In Examining the Private Sector's Role in Wealth Creation and Poverty Reduction (pp. 29-50). https:/ / doi.org/10.4018/978-1-5225-3117-3.ch002

Petter, S., Straub, D., \& Rai, A. (2007). Specifying Formative Constructs in Information Systems Research. MIS Quarterly, 31(4), 623-656. doi:10.2307/25148814

Rigdon, E. E. (2012). Rethinking partial least squares path modeling: In praise of simple methods. Long Range Planning, 45(5-6), 341-358.

Rigdon, E. E., Sarstedt, M.,\&Ringle, C. M. (2017). On comparing results from CBSEM and PLS-SEM: Five perspectives and five recommendations. Marketing ZFP, 39(3), 4-16.

Ringle, C., Wende, S., Becker, J., Ringle, Christian M., Wende, Sven, \& Becker, J.-M., Ringle, C., Wende, S., \& Becker, J. (2015). SmartPLS 3. Retrieved From https://doi.org/http://www.smartpls.com

Roldán, J. L., \& Sánchez-Franco, M. J. (2012). Variance-Based Structural Equation Modeling: Guidelines for Using Partial Least Squares in Information Systems research. In Research Methodologies, Innovations and Philosophies in Software Systems Engineering and Information Systems. https://doi.org/10.4018/978-1-4666-0179-6

Ruiz, F., Cabello, J. M., \& Pérez-Gladish, B. (2018). Building Ease-of-Doing-Business synthetic indicators using a double reference point approach. Technological Forecasting and Social Change, 131, 130-140. https://doi.org/10.1016/j.techfore.2017.06.005

Sarstedt, M., Hair, J. F., Ringle, C. M., Thiele, K. O., \& Gudergan, S. P. (2016). Estimation issues with PLS and CBSEM: Where the bias lies! Journal of Business Research, 69(10), 3998-4010.

Schueth, S. (2011). Assembling international competitiveness: The Republic of Georgia, USAID, and the Doing Business project. Economic geography, 87(1), 51-77. https://doi.org/10.1111/j.1944-8287.2010.01103.x

Shmueli, G. (2010). To explain or to predict? Statistical science, 25(3), 289-310. https://doi.org/10.2139/ssrn.1351252

Shmueli, G., \& Koppius, O. R. (2011). Predictive analytics in information systems research. MIS quarterly, 553-572. doi:10.2139/ssrn.1606674

Shmueli, G., Ray, S., Velasquez Estrada, J. M., \& Chatla, S. B. (2016). The elephant in the room: Predictive performance of PLS models. Journal of Business Research, 69(10), 4552-4564. https://doi.org/10.1016/j.jbusres.2016.03.049

Szirmai, A., Naudé, W., \& Goedhuys, M. (2011). Entrepreneurship, Innovation, and Economic Development. In Entrepreneurship, Innovation, and Economic Development. https://doi.org/10.1093/acprof:oso/9780199596515.001.0001

Szirmai, A., Naudé, W., \& Goedhuys, M. (Eds.). (2011). Entrepreneurship, Innovation, and Economic Development. Oxford: Oxford University Press. https://doi.org/10.1093/acprof:oso/9780199596515.001.0001

World Bank (2008). Doing business: an independent evaluation - taking the measure of the World Bank-IFC Doing Business Indicators (English). Washington, DC: World Bank. Retrieved http://documents.worldbank.org/curated/en/102811468157765042/Doing-business-an-independentevaluation-taking-the-measure-of-the-World-Bank-IFC-Doing-Business-Indicators

Doing Business (2018, October). Doing Business 2018: Reforming to Create Jobs (15 th. Annual Report). World Bank Group. Retrieved from https://www.doingbusiness.org/en/reports/global-reports/doing-business-2018 


\section{APPENDIX}

Table 6

Data

\begin{tabular}{|c|c|c|c|c|c|}
\hline Economy & GDPpc & Ranking GDPpc & HDI & Ranking HDI & EDBI Global Rank \\
\hline Afghanistan & 1981 & 167 & 0.498 & 168 & 167 \\
\hline Albania & 12020 & 98 & 0.785 & 68 & 63 \\
\hline Angola & 6389 & 129 & 0.581 & 147 & 173 \\
\hline Antigua and Barbuda & 23593 & 61 & 0.78 & 70 & 112 \\
\hline Argelia & 15275 & 83 & 0.754 & 85 & 157 \\
\hline Argentina & 20787 & 65 & 0.825 & 47 & 119 \\
\hline Armenia & 9647 & 108 & 0.755 & 83 & 41 \\
\hline Australia & 48460 & 21 & 0.939 & 3 & 18 \\
\hline Austria & 52398 & 16 & 0.908 & 20 & 26 \\
\hline Azaerbaijan & 17398 & 75 & 0.757 & 80 & 25 \\
\hline Bahamas & 30430 & 45 & 0.807 & 54 & 118 \\
\hline Bahrain & 47527 & 23 & 0.846 & 43 & 62 \\
\hline Bangladesh & 3869 & 147 & 0.608 & 136 & 176 \\
\hline Barbados & 18639 & 70 & 0.8 & 58 & 129 \\
\hline Belarus & 18848 & 68 & 0.808 & 53 & 37 \\
\hline Belgium & 47840 & 22 & 0.916 & 17 & 45 \\
\hline Belize & 8590 & 114 & 0.708 & 106 & 125 \\
\hline Benin & 2266 & 162 & 0.515 & 163 & 153 \\
\hline Bhutan & 9560 & 109 & 0.612 & 134 & 81 \\
\hline Bolivia & 7560 & 121 & 0.693 & 118 & 156 \\
\hline Bosnia and Herzegovina & 12876 & 95 & 0.768 & 77 & 89 \\
\hline Botswana & 17354 & 76 & 0.717 & 101 & 86 \\
\hline Brazil & 15484 & 82 & 0.759 & 79 & 109 \\
\hline Brunei & 78836 & 4 & 0.853 & 39 & 55 \\
\hline Bulgaria & 20329 & 66 & 0.813 & 51 & 59 \\
\hline Burkina Faso & 1870 & 170 & 0.423 & 183 & 151 \\
\hline Burundi & 771 & 187 & 0.417 & 185 & 168 \\
\hline Cambodia & 4002 & 144 & 0.582 & 146 & 138 \\
\hline Cameroon & 3694 & 149 & 0.556 & 151 & 166 \\
\hline Canada & 46705 & 24 & 0.926 & 12 & 22 \\
\hline Cape Verde & 6831 & 126 & 0.654 & 125 & 131 \\
\hline Central African Rep & 36327 & 37 & 0.367 & 188 & 183 \\
\hline Chad & 1941 & 168 & 0.404 & 186 & 181 \\
\hline Chile & 24635 & 59 & 0.843 & 44 & 56 \\
\hline China & 16807 & 79 & 0.752 & 86 & 46 \\
\hline Colombia & 14552 & 89 & 0.747 & 90 & 65 \\
\hline Comoros & 1552 & 179 & 0.503 & 165 & 164 \\
\hline Congo Dem Rep & 887 & 185 & 0.457 & 176 & 184 \\
\hline Congo Rep & 5359 & 136 & 0.606 & 137 & 180 \\
\hline Costa Rica & 17044 & 78 & 0.794 & 63 & 67 \\
\hline Cote d'Ivoire & 3953 & 145 & 0.492 & 170 & 122 \\
\hline Croatia & 25264 & 57 & 0.831 & 46 & 58 \\
\hline Cyprus & 34503 & 39 & 0.869 & 32 & 57 \\
\hline Czech Republic & - & 189 & 0.888 & 27 & 35 \\
\hline Denmark & 51364 & 18 & 0.929 & 11 & 3 \\
\hline Djibouti & 2705 & 158 & 0.476 & 172 & 99 \\
\hline Dominica & 10620 & 105 & 0.715 & 103 & 103 \\
\hline Dominican Republic & 16030 & 81 & 0.736 & 94 & 102 \\
\hline
\end{tabular}




\begin{tabular}{|c|c|c|c|c|c|}
\hline Ecuador & 11618 & 101 & 0.752 & 86 & 123 \\
\hline Egypt & 11583 & 102 & 0.696 & 115 & 120 \\
\hline El Salvador & 8006 & 120 & 0.674 & 121 & 85 \\
\hline Equatorial Guinea & 24817 & 58 & 0.591 & 141 & 177 \\
\hline Eritrea & 1510 & 181 & 0.44 & 179 & 189 \\
\hline Estonia & 31742 & 41 & 0.871 & 30 & 16 \\
\hline Eswatini & 8496 & 115 & - & - & 117 \\
\hline Ethiopia & 1899 & 169 & 0.463 & 173 & 159 \\
\hline Fiji & 9554 & 110 & 0.741 & 92 & 101 \\
\hline Finlandia & 44866 & 25 & 0.92 & 15 & 17 \\
\hline France & 42850 & 28 & 0.901 & 24 & 32 \\
\hline Gabon & 18183 & 72 & 0.702 & 110 & 169 \\
\hline Gambia & 1715 & 173 & 0.46 & 174 & 149 \\
\hline Georgia & 10699 & 104 & 0.78 & 70 & 6 \\
\hline Germany & 50638 & 19 & 0.936 & 5 & 24 \\
\hline Ghana & 4641 & 140 & 0.592 & 140 & 114 \\
\hline Greece & 27602 & 50 & 0.87 & 31 & 72 \\
\hline Grenada & 14924 & 87 & 0.772 & 75 & 147 \\
\hline Guatemala & 8150 & 119 & 0.65 & 127 & 98 \\
\hline Guinea & 2285 & 161 & 0.459 & 175 & 152 \\
\hline Guinea-Bissau & 1700 & 174 & 0.455 & 177 & 175 \\
\hline Guyana & 8163 & 118 & 0.654 & 125 & 134 \\
\hline Haiti & 1815 & 172 & 0.498 & 168 & 182 \\
\hline Honduras & 4986 & 138 & 0.617 & 133 & 121 \\
\hline Hong Kong & 61540 & 10 & 0.933 & 7 & 4 \\
\hline Hungary & 28107 & 49 & 0.838 & 45 & 53 \\
\hline Iceland & 53152 & 14 & 0.935 & 6 & 21 \\
\hline India & 7056 & 123 & 0.64 & 130 & 77 \\
\hline Indonesia & 12284 & 97 & 0.694 & 116 & 73 \\
\hline Iran & 20949 & 64 & 0.798 & 60 & 128 \\
\hline Iraq & 17196 & 77 & 0.685 & 120 & 171 \\
\hline Ireland & 75648 & 5 & 0.938 & 4 & 23 \\
\hline Israel & 38262 & 34 & 0.903 & 22 & 49 \\
\hline Italy & 39426 & 32 & 0.88 & 28 & 51 \\
\hline Jamaica & 8995 & 112 & 0.732 & 97 & 75 \\
\hline Japan & 43279 & 26 & 0.909 & 19 & 39 \\
\hline Jordan & 9153 & 111 & 0.735 & 95 & 104 \\
\hline Kazakhstan & 26410 & 54 & 0.8 & 58 & 28 \\
\hline Kenia & 3286 & 152 & 0.59 & 142 & 61 \\
\hline Kiribati & 2175 & 164 & 0.612 & 134 & 158 \\
\hline Korea & 38335 & 33 & 0.903 & 22 & 5 \\
\hline Kosovo & 10754 & 103 & - & - & 44 \\
\hline Kuwait & 71943 & 7 & 0.803 & 56 & 97 \\
\hline Kyrgyzstan & 3726 & 148 & - & - & 70 \\
\hline Laos & 7023 & 124 & 0.601 & 139 & 154 \\
\hline Latvia & 27598 & 51 & 0.847 & 41 & 19 \\
\hline Lebanon & 14676 & 88 & 0.757 & 80 & 142 \\
\hline Lesotho & 3130 & 155 & 0.52 & 159 & 106 \\
\hline Liberia & 827 & 186 & 0.435 & 181 & 174 \\
\hline Lithuania & 32093 & 40 & 0.858 & 35 & 14 \\
\hline Luxembourg & 103744 & 2 & 0.904 & 21 & 66 \\
\hline Lybia & 19631 & 67 & 0.706 & 108 & 186 \\
\hline Macedonia & 15231 & 84 & 0.757 & 80 & 10 \\
\hline Madagascar & 1555 & 178 & 0.519 & 161 & 161 \\
\hline
\end{tabular}




\begin{tabular}{|c|c|c|c|c|c|}
\hline Malawi & 1202 & 183 & 0.477 & 171 & 111 \\
\hline Malaysia & 29432 & 46 & 0.802 & 57 & 15 \\
\hline Maldives & 16669 & 80 & 0.717 & 101 & 139 \\
\hline Mali & 2211 & 163 & 0.427 & 182 & 145 \\
\hline Malta & 39535 & 31 & 0.878 & 29 & 84 \\
\hline Marshal Islands & 4193 & 142 & 0.708 & 106 & 150 \\
\hline Mauritania & 3950 & 146 & 0.52 & 159 & 148 \\
\hline Mauritius & 22278 & 63 & 0.79 & 65 & 20 \\
\hline Mexico & 18258 & 71 & 0.774 & 74 & 54 \\
\hline Micronesia & 3622 & 150 & 0.627 & 131 & 160 \\
\hline Moldova & 5698 & 133 & 0.7 & 112 & 47 \\
\hline Mongolia & 13000 & 94 & 0.741 & 92 & 74 \\
\hline Montenegro & 18765 & 69 & 0.814 & 50 & 50 \\
\hline Morocco & 8218 & 117 & 0.667 & 123 & 60 \\
\hline Mozambique & 1247 & 182 & 0.437 & 180 & 135 \\
\hline Myanmar & 6139 & 130 & - & - & 171 \\
\hline Namibia & 10475 & 106 & 0.647 & 129 & 107 \\
\hline Nepal & 2682 & 159 & 0.574 & 149 & 110 \\
\hline Netherlands & 52503 & 15 & 0.931 & 10 & 36 \\
\hline New Zealand & 41109 & 30 & 0.917 & 16 & 1 \\
\hline Nicaragua & 5482 & 135 & 0.658 & 124 & 132 \\
\hline Niger & 1017 & 184 & 0.354 & 189 & 143 \\
\hline Nigeria & 5861 & 132 & 0.532 & 157 & 146 \\
\hline Norway & 61414 & 11 & 0.953 & 1 & 7 \\
\hline Oman & 41675 & 29 & 0.821 & 48 & 78 \\
\hline Pakistan & 5527 & 134 & 0.562 & 150 & 136 \\
\hline Palau & 14536 & 90 & 0.798 & 60 & 133 \\
\hline Panama & 24446 & 60 & 0.789 & 66 & 79 \\
\hline Papua New Guinea & 4197 & 141 & 0.544 & 153 & 108 \\
\hline Paraguay & 9690 & 107 & 0.702 & 110 & 113 \\
\hline Peru & 13434 & 93 & 0.75 & 89 & 68 \\
\hline Phillipines & 8343 & 116 & 0.699 & 113 & 124 \\
\hline Poland & 29026 & 47 & 0.865 & 33 & 33 \\
\hline Portugal & 31672 & 42 & 0.847 & 41 & 34 \\
\hline Puerto Rico & 37793 & 36 & - & - & 64 \\
\hline Qatar & 128378 & 1 & 0.856 & 37 & 83 \\
\hline Romania & 25840 & 55 & 0.811 & 52 & 52 \\
\hline Russia & 25533 & 56 & 0.816 & 49 & 31 \\
\hline Rwanda & 2036 & 166 & 0.524 & 158 & 29 \\
\hline Saint Kitts and Nevis & 27066 & 52 & 0.778 & 72 & 140 \\
\hline Saint Vincent and the Grenadines & 11776 & 100 & 0.723 & 99 & 130 \\
\hline Samoa & 6611 & 128 & 0.713 & 104 & 90 \\
\hline San Marino & 62425 & 9 & - & - & 88 \\
\hline Santa Lucía & 14219 & 91 & 0.747 & 90 & 93 \\
\hline Sao Tomé and Príncipe & 3351 & 151 & 0.589 & 143 & 170 \\
\hline Saudi Arabia & 53845 & 13 & 0.853 & 39 & 92 \\
\hline Senegal & 2712 & 157 & 0.505 & 164 & 141 \\
\hline Serbia & 15090 & 86 & 0.787 & 67 & 48 \\
\hline Seychelles & 28963 & 48 & 0.797 & 62 & 96 \\
\hline Sierra Leone & 1526 & 180 & 0.419 & 184 & 163 \\
\hline Singapoore & 93905 & 3 & 0.932 & 9 & 2 \\
\hline Slovakia & 31616 & 43 & 0.855 & 38 & 42 \\
\hline Slovenia & 34868 & 38 & 0.896 & 25 & 40 \\
\hline Solomon Islands & 2422 & 160 & 0.546 & 152 & 115 \\
\hline
\end{tabular}




\begin{tabular}{|c|c|c|c|c|c|}
\hline Somalia & 600 & 188 & - & - & 190 \\
\hline South Africa & 13498 & 92 & 0.699 & 113 & 82 \\
\hline South Sudan & 1693 & 175 & 0.388 & 187 & 185 \\
\hline Spain & 37998 & 35 & 0.891 & 26 & 30 \\
\hline Sri Lanka & 12811 & 96 & 0.77 & 76 & 100 \\
\hline Sudan & 4903 & 139 & 0.502 & 167 & 162 \\
\hline Suriname & 15114 & 85 & 0.72 & 100 & 165 \\
\hline Sweden & 50208 & 20 & 0.933 & 7 & 12 \\
\hline Switzerland & 64712 & 8 & 0.944 & 2 & 38 \\
\hline Syria & 5285 & 137 & - & - & 179 \\
\hline Taiwan & 52304 & 17 & - & - & 13 \\
\hline Tajikistan & 3180 & 154 & 0.65 & 127 & 126 \\
\hline Tanzania & 2946 & 156 & 0.538 & 154 & 144 \\
\hline Thailand & 17870 & 73 & 0.755 & 83 & 27 \\
\hline Timor-Leste & 7213 & 122 & 0.625 & 132 & 178 \\
\hline Togo & 1570 & 177 & 0.503 & 165 & 137 \\
\hline Tonga & 5957 & 131 & 0.726 & 98 & 91 \\
\hline Trinidad and Tobago & 31578 & 44 & 0.784 & 69 & 105 \\
\hline Tunissia & 11911 & 99 & 0.735 & 95 & 80 \\
\hline Turkey & 26505 & 53 & 0.791 & 64 & 43 \\
\hline Uganda & 1864 & 171 & 0.516 & 162 & 127 \\
\hline Ukraine & 8667 & 113 & 0.751 & 88 & 71 \\
\hline United Arab Emirates & 73878 & 6 & 0.863 & 34 & 11 \\
\hline United Kingdom & 43269 & 27 & 0.922 & 14 & 9 \\
\hline Uruguay & 22562 & 62 & 0.804 & 55 & 95 \\
\hline USA & 59531 & 12 & 0.924 & 13 & 8 \\
\hline Uzbekistan & 6865 & 125 & 0.71 & 105 & 76 \\
\hline Vanuatu & 3208 & 153 & 0.603 & 138 & 94 \\
\hline Venezuela & 17640 & 74 & 0.761 & 78 & 188 \\
\hline Viet Nam & 6676 & 127 & 0.694 & 116 & 69 \\
\hline West Bank and Gaza & - & 190 & - & - & 116 \\
\hline Yemen & 1595 & 176 & 0.452 & 178 & 187 \\
\hline Zambia & 4050 & 143 & 0.588 & 144 & 87 \\
\hline Zimbabwe & 2086 & 165 & 0.535 & 156 & 155 \\
\hline
\end{tabular}


Table 7

Indicators correlations

\begin{tabular}{|c|c|c|c|c|c|c|c|c|c|c|c|c|c|c|c|}
\hline & $\begin{array}{c}\text { GDP } \\
\mathrm{pc}\end{array}$ & $\begin{array}{c}\text { Ranki } \\
\text { ng } \\
\text { GDP } \\
\text { pc }\end{array}$ & HDI & $\begin{array}{c}\text { Ranki } \\
\text { ng } \\
\text { HDI }\end{array}$ & $\begin{array}{c}\text { Globa } \\
1 \\
\text { Rank }\end{array} \mid$ & $\begin{array}{l}\text { Busine } \\
\text { ss } \\
\text { Openi } \\
\text { ng }\end{array}$ & $\begin{array}{l}\text { Buildi } \\
\text { ng } \\
\text { Permit } \\
\text { s }\end{array}$ & $\begin{array}{c}\text { Electrici } \\
\text { ty } \\
\text { Obtaini } \\
\text { ng }\end{array}$ & $\begin{array}{c}\text { Property } \\
\text { Registrati } \\
\text { on }\end{array}$ & $\begin{array}{c}\text { Credit } \\
\text { Obtaini } \\
\text { ng }\end{array}$ & \begin{tabular}{|c|} 
Protecti \\
on \\
Minority \\
Investor \\
$\mathrm{s}$ \\
\end{tabular} & $\begin{array}{c}\text { Taxes } \\
\text { Payme } \\
\text { nt }\end{array}$ & \begin{tabular}{|c|} 
Cross \\
- \\
borde \\
r \\
Trade \\
\end{tabular} & $\mid \begin{array}{c}\text { Contract } \\
\text { s } \\
\text { Fulfillme } \\
\text { nt }\end{array}$ & $\begin{array}{c}\text { Insolven } \\
\text { cy } \\
\text { Resoluti } \\
\text { on }\end{array}$ \\
\hline GDP pc & 1.000 & & & & & & & & & & & & & & \\
\hline Ranking GDP pc & -0.859 & 1.000 & & & & & & & & & & & & & \\
\hline HDI & 0.497 & -0.538 & 1.000 & & & & & & & & & & & & \\
\hline Ranking HDI & -0.779 & 0.899 & -0.569 & 1.000 & & & & & & & & & & & \\
\hline Global Rank & -0.588 & 0.673 & -0.391 & 0.782 & 1.000 & & & & & & & & & & \\
\hline Business Opening & -0.382 & 0.399 & -0.181 & 0.465 & 0.660 & 1.000 & & & & & & & & & \\
\hline Building Permits & -0.518 & 0.566 & -0.339 & 0.588 & 0.676 & 0.513 & 1.000 & & & & & & & & \\
\hline Electricity Obtaining & -0.577 & 0.647 & -0.361 & 0.709 & 0.791 & 0.474 & 0.575 & 1.000 & & & & & & & \\
\hline Property Registration & -0.460 & 0.494 & -0.309 & 0.612 & 0.802 & 0.481 & 0.511 & 0.584 & 1.000 & & & & & & \\
\hline Credit Obtaining & -0.197 & 0.279 & -0.219 & 0.382 & 0.688 & 0.398 & 0.324 & 0.403 & 0.503 & 1.000 & & & & & \\
\hline $\begin{array}{l}\text { Protection Minority } \\
\text { Investors }\end{array}$ & -0.353 & 0.463 & -0.217 & 0.527 & 0.759 & 0.567 & 0.471 & 0.530 & 0.544 & 0.544 & 1.000 & & & & \\
\hline Taxes Payment & -0.582 & 0.559 & -0.349 & 0.638 & 0.737 & 0.489 & 0.567 & 0.580 & 0.617 & 0.344 & 0.477 & 1.000 & & & \\
\hline Cross-border Trade & -0.466 & 0.544 & -0.356 & 0.683 & 0.759 & 0.405 & 0.481 & 0.585 & 0.605 & 0.405 & 0.437 & 0.568 & 1.000 & & \\
\hline Contracts Fulfillment & -0.488 & 0.567 & -0.343 & 0.629 & 0.738 & 0.491 & 0.524 & 0.598 & 0.616 & 0.389 & 0.515 & 0.582 & 0.568 & 1.000 & \\
\hline Insolvency Resolution & -0.490 & 0.571 & -0.321 & 0.654 & 0.805 & 0.537 & 0.425 & 0.606 & 0.545 & 0.506 & 0.643 & 0.498 & 0.621 & 0.493 & 1.000 \\
\hline
\end{tabular}

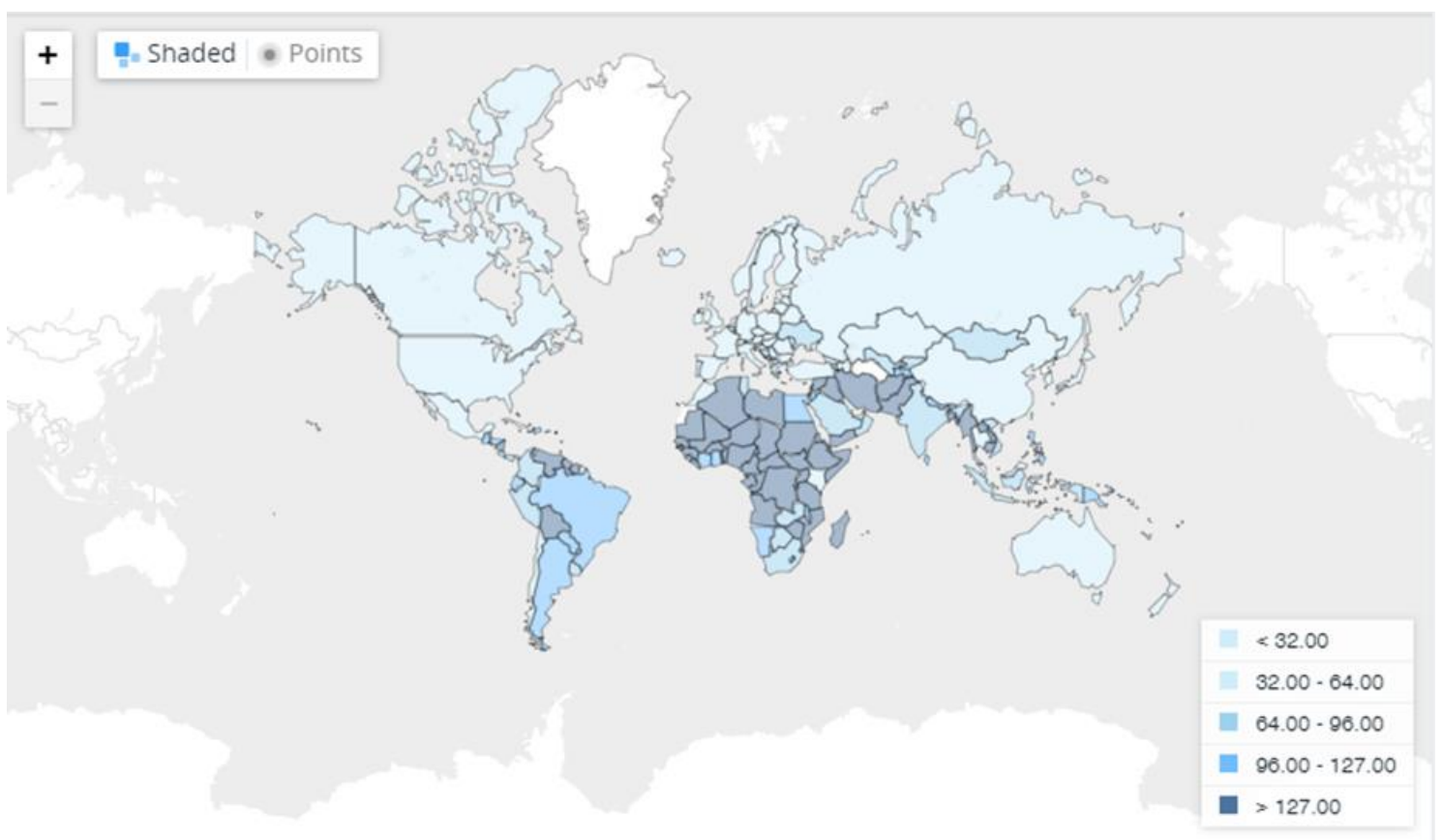

Figure 2. Countries by EDBI in 2018 


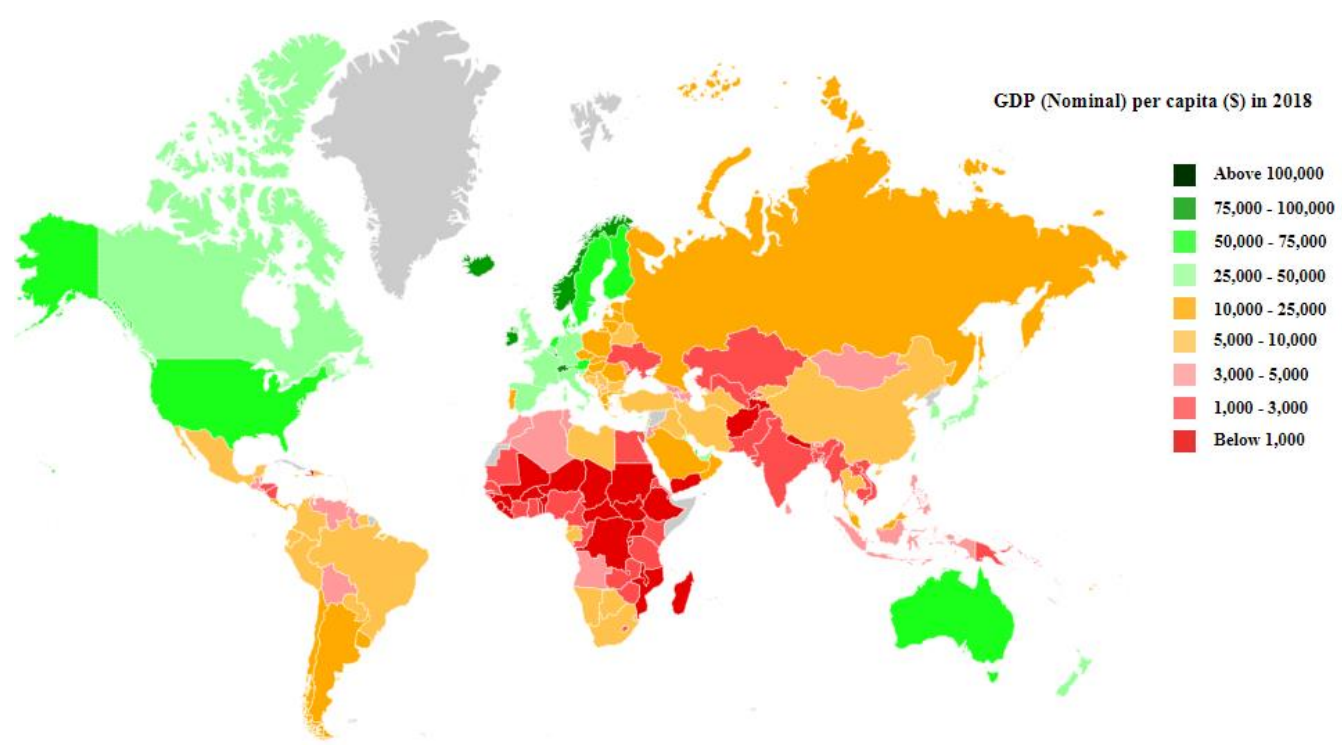

Figure 3. Countries by GDP pc in 2018

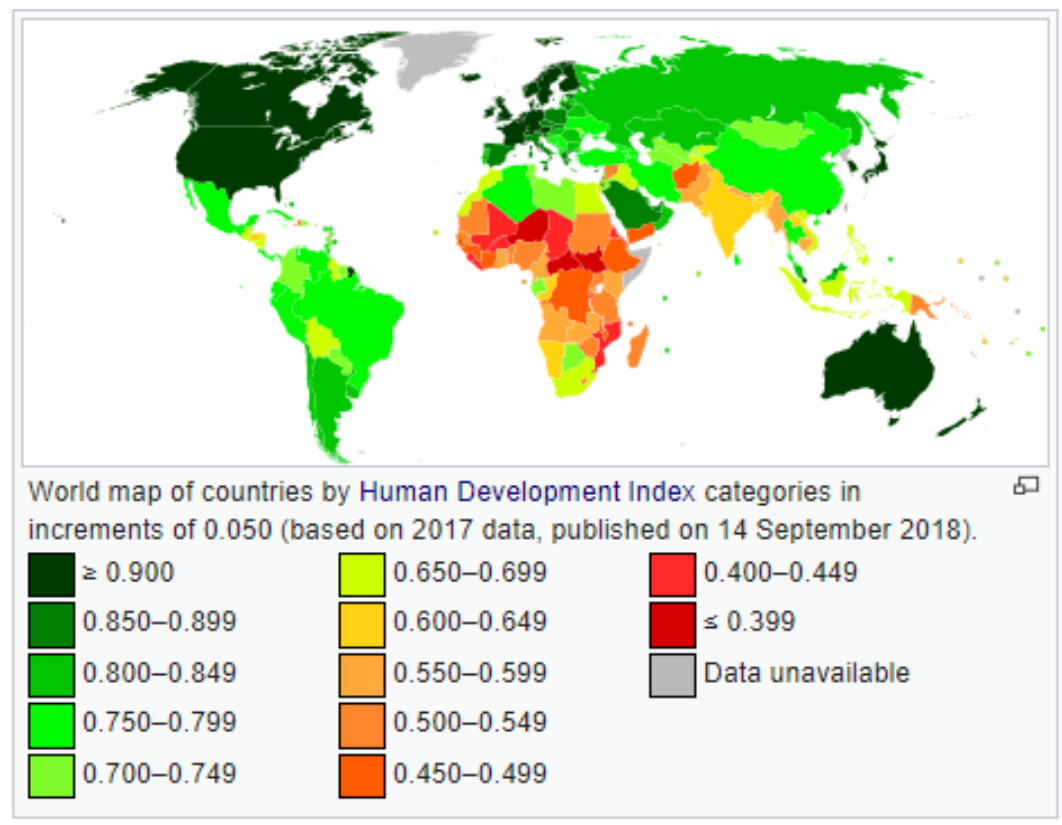

Figure 4. Countries by HDI in 2018 